\title{
Development and Sensory Evaluation of Wheat Flour Chapati Grown under Six Agro Management Practices
}

\author{
Kusum Sharma*, Nikita Wadhawan and Sunidhi Mishra \\ College of community and applied sciences, MPUAT, Udaipur, India \\ *Corresponding author
}

\begin{tabular}{l} 
Key w o r d s \\
Agriculture, \\
Pesticides, Organic, \\
Conventional, \\
Sensory \\
characteristics and \\
Agro management \\
\hline Article Info \\
\hline $\begin{array}{l}\text { Accepted: } \\
11 \text { June } 2020 \\
\text { Available Online: } \\
\text { 10 July } 2020\end{array}$ \\
\hline
\end{tabular}

\section{Keywords}

Agriculture, Pesticides, Organic Conventional, Sensory Agro management

Article Info

Accepted:

Available Online

July 2020

\section{A B S T R A C T}

Agriculture is an important sector of the Indian economy. About half of the population relies on agriculture, as it is the principal source of income. From last 30 decades the use of pesticides for increasing the crop production is also increased. After green revolution increased demand of food and increased use of pesticides causes cancer in different state of the country. Combating cancer is a challenge for the new generation. In this paper emphasis gives on shift from pesticides to organic management of agriculture. The single variety of wheat (Raj 4120) of different treatment is used as a value added product namely wheat Chapati. Due to different treatments flour was not enriched with other flours as it change the original sensory values. Six types of treatments are $100 \%$ organic, 75 $\%$ organic $+25 \%$ innovative practices, $50 \%$ organic and $50 \%$ inorganic, $75 \%$ organic $+25 \%$ pesticides, $100 \%$ inorganic and state recommendations. All these six flours marked as T1, T2, T3, T4, T5 and T6. The Chapati was standardized through sensory evaluation by trained members of the panel on 9-point hedonic rating scale. Sensory evaluation showed that Chapati prepared from T1 was highly accepted as it has scored high in all scores followed by T2 and T3 management of wheat flour.

\section{Introduction}

India accounts for only about 2.4 per cent of the world's geographical area and 4 per cent of its water resources, but has to support about 17 per cent of the world's human population and 15 per cent of the livestock. Agriculture is an important sector of the Indian economy, accounting for 14 per cent of the nation's GDP, about 11 per cent of its exports, about half of the population still relies on agriculture as its principal source of income and it is a source of raw material for a large number of industries. Accelerating the growth of agriculture production is therefore necessary to meet the rising demand for food, and also to increase incomes of those dependent on agriculture to ensure inclusiveness (GOI, 2013). 
India currently holds the ninth position among 178 countries that actively practice organic agriculture. At present, the country is home to more than 835,000 organic producers, 699 processors, 669 exporters and 1.49 million ha area under organic cultivation (Bordoloi, 2018). However, with only a meager $0.4 \%$ of the total agricultural land area designated for organic cultivation, the industry presents extensive scope for expansion (WOASET, 2018).

After green revolution increased demand of food and increased use of pesticides causes cancer in different states of the country. Combating cancer is a challenge for the new generation. In this paper emphasis gives on shift from pesticides to organic management of agriculture.

Hence, from all food grains wheat is the staple cereal crop selected for the Development and Sensory Evaluation of Wheat Chapati grown under six agro Management as the consumption of wheat flour is more in all parts of the country as compared to other grain.

\section{Materials and Methods}

\section{Locale of the study}

The study was conducted in the Department of Foods and Nutrition, CCAS, MPUAT, Udaipur.

\section{Selection and procurement of sample}

One staple cereal food crops of Rajasthan namely wheat (Triticum Aestivum) variety Raj 4120 grown under six agro management practices was purposively selected for the study purpose from the Rajasthan College of agriculture, under the Network Project on Organic Farming, MPUAT, Udaipur.
These six crop management are as under

CM 1: (T1) $100 \%$ Organic

CM 2: (T2) $75 \%$ Organic $+25 \%$ innovative practices like Matka Khad and Panchgavya.

CM 3: (T3) 50\% Organic +50 \% Inorganic (Fertilizer and Chemical Management)

CM 4: (T4) $75 \%$ Organic + $25 \%$ Inorganic (Fertilizer and Chemical Management)

CM 5: (T5) $100 \%$ Inorganic Nutrient Sources CM 6: (T6) State Recommendation (10 t FYM/ha once in 2 years + Fertilizers + pesticides as given in the crop production guide of state).

To avoid varietal difference single lot of wheat was collected and analyzed in triplicate for the sensory evaluation.

\section{Development of recipes}

Wheat chapati was developed from all six agro management.

\section{Standardization of recipe}

Each time chapati was prepared by incorporating only salt in all six agro flours as organically grown wheat may change its original sensory attributes.

\section{Development of score card and Sensory evaluation}

The prepared chapati were subjected to sensory evaluation with respect to color, texture, flavor, taste, appearance and overall acceptability by a semi trained panel of ten judges using 9- point hedonic rating scale (Williams, 1989).

\section{Results and Discussion}

The results obtained on the basis of sensory attributes in all six agro management practices. 


\section{Development of chapati}

The developed flour of wheat was taken to prepare chapati from all six agro management wheat. Only salt was added to flours and it was not enriched with any other flour as this may change its original sensory attributes.

\section{Standardisation}

Developed six agro management chapattis were used as a value added products for judging their acceptability. Ten semi trained panel members were selected for sensory evaluation.

Table 1 shows that cooked weight of all six chapattis for one serving were found highest in T5 (100\% Inorganic) followed by T2 (75\% Organic $+25 \%$ Innovative practces) and $\mathrm{T} 6$ (state recommendation). Table also showed that T1 (100\%organic) required maximum amount of water for dough kneading process. This may be due to more gluten content but after cooking its cooked weight found lowest than other agro management grown wheat flour.

It is evident from the table 2 that the scores given by panel for different sensory attributes in three trials were slightly different. Recipes developed were highly accepted by members of the panel. The scores given to T1 (100\% Organic wheat flour) was highest from all six agro management and liked more by panelists followed by T2 $(75 \%$ organic $+25 \%$ innovative practices) and T3 (50\% organic $50 \%$ inorganic fertilizers). High scores may be due to no use of pesticides and fertilizers in $\mathrm{T} 1$ and $\mathrm{T} 2$. The obtained chapatti of all six agro management wheat flour was compared to their sensory attributes. In colour, appearance and doneness $100 \%$ organic CM (T1) shows significant difference $(\mathrm{P}>0.05)$ between all other crop management (CM) except T2 and T3 while texture shows significant difference $(\mathrm{P}>0.05)$ between all other CM. In flavor there were no significant difference were found between $100 \%$ organic $\mathrm{CM}$ and $100 \%$ inorganic CM. Developed chapatti of $100 \%$ organic (T1) flour was showed significant difference between all CM except $75 \%$ organic+ $25 \%$ innovative practices (T2) in taste and overall value .Xin Zhao et.al. (2007) reported that fruits and vegetables grown organically were found better $\mathrm{n}$ taste than conventionally grown produce. In the study they state that $72 \%$ consumers considered organic produce as these were healthier while $28 \%$ favored for the better taste than conventionally grown vegetables.

Table.1 Water requirement, weight of dough and cooked weight of chapatis

\begin{tabular}{|c|c|c|c|c|}
\hline Treatments & Flour Taken & $\begin{array}{c}\text { Water needed } \\
(\mathbf{m l})\end{array}$ & $\begin{array}{l}\text { Weight of dough } \\
\text { (g)/serving }\end{array}$ & $\begin{array}{l}\text { Cooked Weight } \\
\text { (g)/ serving }\end{array}$ \\
\hline $\mathrm{T} 1$ & \multirow[t]{6}{*}{$30 \mathrm{gm}$} & 30 & 52.4 & 45.4 \\
\hline $\mathrm{T} 2$ & & 25 & 53.3 (III) & 47.5 (II) \\
\hline $\mathrm{T} 3$ & & 25 & 52.3 & 46.3 \\
\hline $\mathrm{T} 4$ & & 25 & 52.0 & 46.1 \\
\hline T5 & & 24 & $53.9(I)$ & 47.9 (I) \\
\hline T6 & & 23 & 53.5 (II) & 46.9 (III) \\
\hline
\end{tabular}


Table.2 Acceptability of recipe using sensory evaluation

\begin{tabular}{|c|c|c|c|c|c|c|c|}
\hline Treatment & Colour & Taste & Flavour & Texture & Appearance & doneness & Overall \\
\hline 1 & $\mathbf{8 . 1 0}$ & $\mathbf{8 . 2 0}$ & $\mathbf{7 . 8 3}$ & $\mathbf{8 . 1 3}$ & $\mathbf{8 . 0 3}$ & $\mathbf{8 . 2 0}$ & $\mathbf{8 . 3 0}$ \\
\hline 2 & 8.03 & 7.83 & 7.60 & 7.90 & 7.93 & 8.04 & 8.07 \\
\hline 3 & 7.80 & 7.47 & 7.40 & 7.37 & 7.73 & 7.87 & 7.57 \\
\hline 4 & 7.57 & 7.43 & 7.33 & 7.35 & 7.30 & 7.60 & 7.45 \\
\hline 5 & 7.47 & 7.07 & 7.47 & 7.30 & 7.17 & 7.60 & 7.40 \\
\hline 6 & 7.52 & 7.30 & 7.13 & 7.40 & 7.37 & 7.63 & 7.50 \\
\hline SEm \pm & 0.13 & 0.20 & 0.13 & 0.21 & 0.14 & 0.14 & 0.21 \\
\hline CD at $5 \%$ & 0.40 & 0.61 & 0.39 & 0.62 & 0.43 & 0.41 & 0.62 \\
\hline CV $(\%)=$ & 3.42 & 5.34 & 3.47 & 5.43 & 3.73 & 3.46 & 5.31 \\
\hline
\end{tabular}

Glimpses of developed recipes

Weighing of Flour Formation of dough
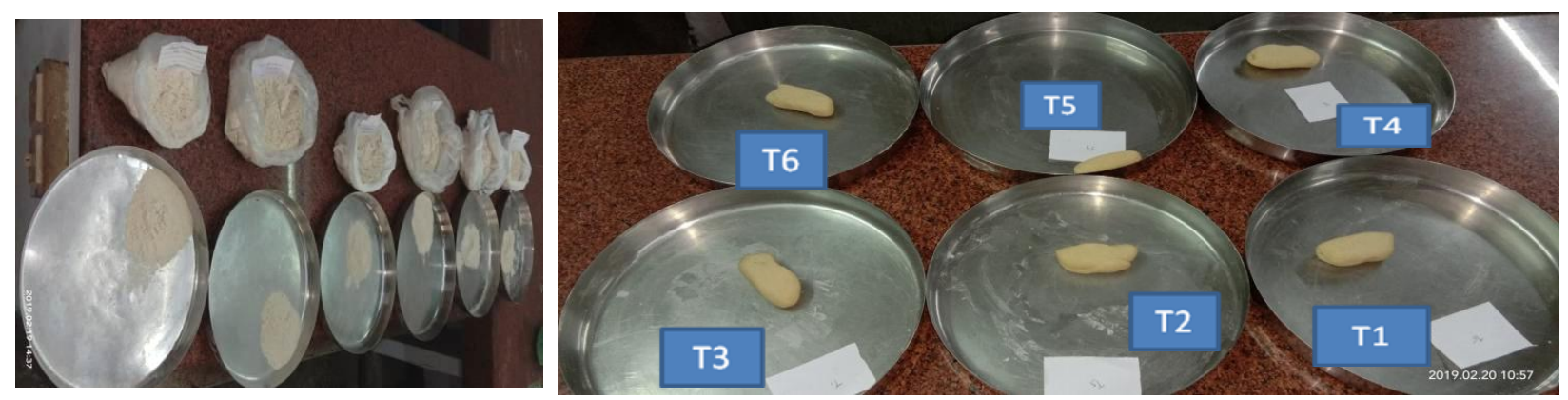

Developed Chapatis

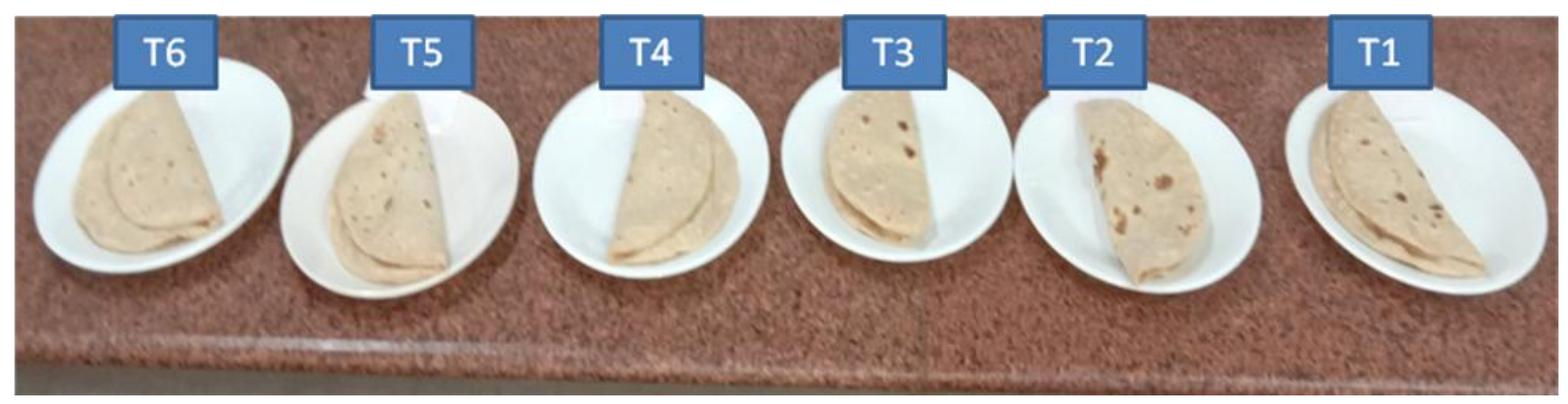




\section{Sensory evaluation}
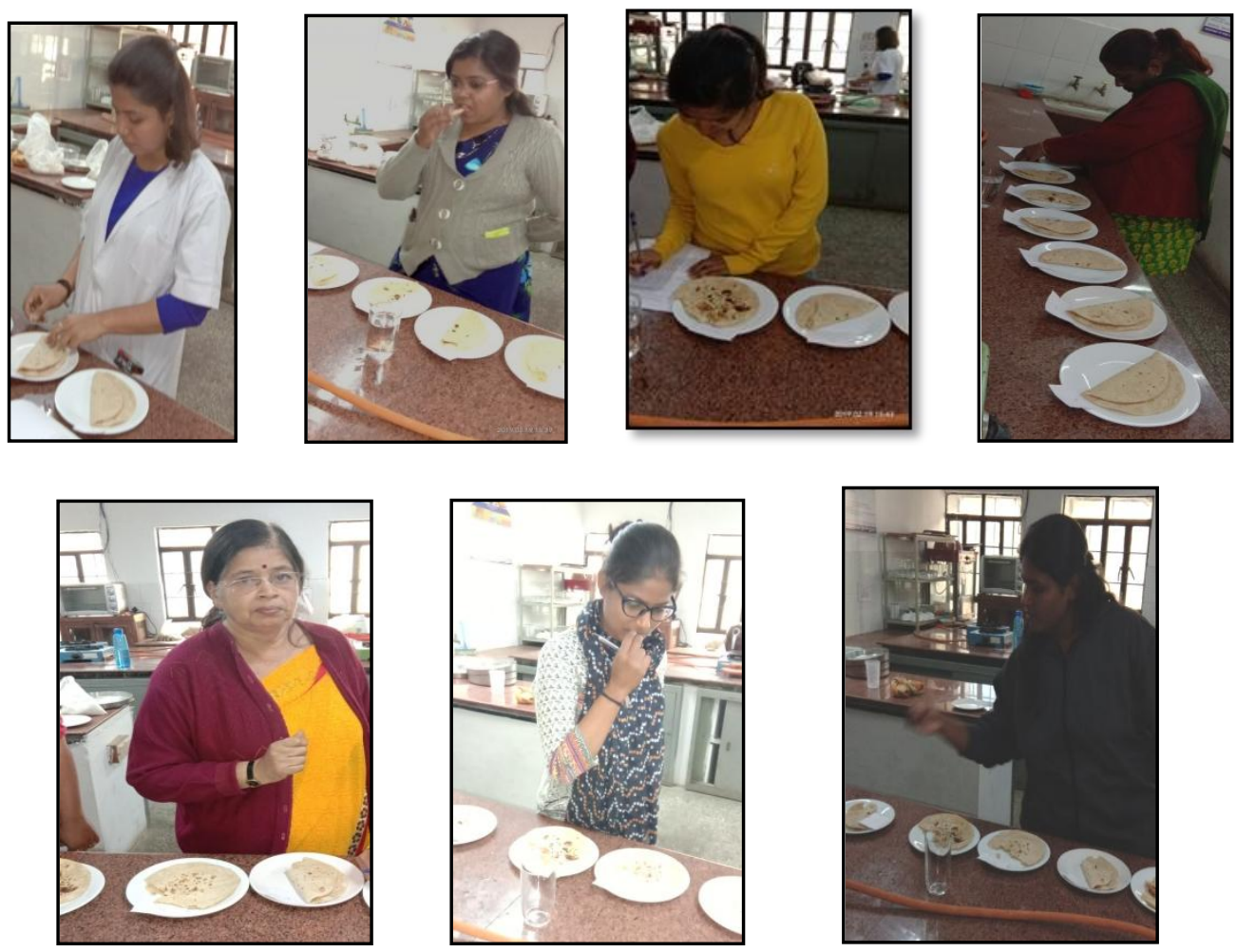

Least scores were found in T5 (100\% inorganic). Nearly similar scores were obtained by $\mathrm{T} 4$ and T6. Least scores may be due to use of pesticides and fertilizers. Similar study was also found by Dholakia jalpa and Shukul Maneesha (2015). Study was conducted in Vadodara district, Gujarat. They were selected same vegetables and fruits in organic and non organic food. They compared the foods in terms of flavour, taste, aroma and texture and found that organic food was better in all sensory attributes than non organic foods.

It is concluded, from all cereal grains wheat is the staple cereal of all Indians as it is cheaper and nutritious along with enough amount of protein, carbohydrates and energy. Green revolution, increased population and hunger makes increased demand for food which makes farmers to produce more crops using higher quantity of fertilizers and pesticides.
But increased use of fertilizers and pesticides spreads various kind of diseases especially cancers and allergies in all parts of the country. Single variety of wheat (Triticum aestivum) RAJ 4120 grown in same soil and climate condition in six agro management have different sensory qualities but from all these management $100 \%$ organic crop management was found best in all sensory attributes as this particular management is free from fertilizers and pesticides. Life style of today's generation needs to shift from pesticides to organic management of agriculture and use of more and more organically grown crops as these are fits best in its sensory qualities as compared to inorganically grown crops.

\section{References}

Dholakia jalpa and Shukul Maneesha. Sensory Evaluation Test of Organic 
and Non Organic Food. 2015. Journal of Environmental Research and Development. Vol.9 No.3A, JanuaryMarch.

Government of India. 2013. State of Indian Agriculture. Ministry of Agriculture, New Delhi, 01. Retrieved on 31.07.2018.

Joshi, M. 1999. Green revolution and its impacts, 10. http://shodhganga.inflibnet.ac.in/bitstr eam/10603/121515/12/12_chapter3.pd f. Retrieved on 01.8.2018.

The World of Organic Agriculture Statistics and Emerging Trend (WOASET).FiBL and IFOAM.2018. Organics International FIBL and
IFOAM Website https://shop.fibl.org/CHen/mwdownlo ads/download/link/id/1093/?ref=1Retr ieved on 31.07.2018.

Williams, M. 1989. Objective evaluation in Food Experimental Perspectives. II ed. Mac. Millan Publishing Company, New York: 80.

Xin Zhao, Edgar Chambers IV, Zaid Malta, Thomas M. Longhin and Edward E. Carey. Consumer Sensory Analysis of Organically and Conventionally Grown Vegetables. 2007. Journal of Food Science. https://doi.org/10.1111/j.17503841.2007.002777.x retrieved on 21.06.2020.

\section{How to cite this article:}

Kusum Sharma, Nikita Wadhawan and Sunidhi Mishra. 2020. Development and Sensory Evaluation of Wheat Flour Chapati Grown under Six Agro Management Practices. Int.J.Curr.Microbiol.App.Sci. 9(07): 1080-1085. doi: https://doi.org/10.20546/ijcmas.2020.907.126 